\title{
Where Have All the Volumes Gone? A Contribution to the Discussion of "Captured Cultural Property" and "Trophy Commissions"
}

\section{Ingo Kolasa}

\begin{abstract}
During and after World War II, Soviet leaders ordered a massive transfer of library holdings and art from German territory to the Soviet Union, establishing "trophy commissions" that organized the systematic removal of public and private collections and allocated them to Soviet libraries, archives, and museums. Some materials were permanently integrated into Russian holdings, but others were poorly stored and forgotten, for lack of staff and space to process them. Only now, as previously secret documents are becoming available to scholars, is it possible to begin to determine what was transferred where, by whose authority, by what methods, and to what ends. The author suggests it is time, fifty years after the end of the war, for Germans and Russians to aid each other in locating and returning missing cultural property.
\end{abstract}

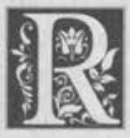

ecently, the author had the opportunity to examine copies of historical documents from a variety of archives in Moscow. These documents disclose facts previously unknown in Russia (and certainly in Germany) about events that occurred some fifty years ago, but whose palpable aftereffects on the German cultural landscape remain.

This article aims to shed light on these events, today diplomatically described as the "war-related transfer of cultural property." Much has been written about the theft and destruction of Russian cultural property by German troops during World War II. Priceless Russian cultural treasures were ruined or stolen, never to be seen again. Having lived for some time in St. Petersburg, the author was able to observe for himself the tremendous losses occasioned by German troops, to say nothing of the feeling toward Germany harbored by citizens of St. Petersburg, where nearly every family displays a photo of a relative killed during the war.

For these reasons, the author hesitated a long time before writing about the fate of German cultural property transported to the Soviet Union by the Red Army in the years 1945 to 1948 . However, the stalled negotiations between the Federal Republic of Germany and the Russian Federation finally convinced him to do so. This regrettable situation has arisen in spite of the existence of legally bind- 
ing accords, in which both countries agree that "missing or unlawfully transferred art treasures located within their territories shall be returned to the owners or their heirs." 1

It is well known that for years the former Soviet Union denied having undertaken a large-scale removal of German cultural property. Few witnesses are left, and most of them were sworn to secrecy. Only after the onset of the gradual democratization - and disintegrationof the Soviet Union were a few hesitant comments made on this topic. In this re-

Much of this material is most likely unknown even to Russian librarians, as it was inaccessible until recently.

gard, the contribution of Evgenii Kuzmin to a December 1992 roundtable in Moscow concerning restitution of cultural property deserves particular mention. ${ }^{2}$ He reported for the first time events that had been carefully concealed from the public, but his assessment found little acceptance among many Russian librarians. This is all too understandable, given the Soviet Union's repeated postwar declarations that it considered the evacuated German cultural property compensation for its own losses.

This article is not meant as a comment on the Russian public's sense of justice, nor as a legal assessment of the situation. Rather, it is an attempt to elucidate the work of the so-called Soviet trophy commissions, based on a study of material from Russian archives. Much of this material is most likely unknown even to Russian librarians, as it was inaccessible until recently.

\section{The Organized Transfer of Cultural Property}

The first link in the chain of events was usually a brief dispatch from a Red Army unit to the district High Command re- porting the discovery of cultural property. The staffs of the district High Commands collected and submitted these reports to the head of the Soviet Military Administration in Germany, which dispatched specialists to evaluate and classify the property.

The next link in the chain of these massive removals was the decision-makers' instructions regarding disposition of the roughly sorted and cursorily evaluated discoveries. Thus, for example, the military commandant of the district of Stollberg received instructions to send to the Soviet Union any valuable books from the Zwickau city library; he was to deliver the remaining volumes to "local agents of self-government" for the restoration of their library. ${ }^{3}$

As a rule, the more or less carefully selected items were brought to collecting points near Berlin railway stations; ${ }^{4}$ from there they traveled to the Soviet Union in special transports. On July 23, 1946, for example, 6,257 crates of books from various libraries, amassed in a warehouse in Berlin, were ordered sent to Leningrad for the State Agency for Literature, or "Gosfond," at the SaltykovShchedrin Library. ${ }^{5}$ The Soviet government had created this agency to allocate the confiscated literature to Soviet libraries and cultural institutions. The Gosfond attempted to apportion the "trophy holdings" in such a way that they would represent meaningful additions to existing collections. At least, this was the project's initial intent. That the huge volume of literature arriving from Germany caused the system to degenerate into a purely mechanical process, and that the beneficiary libraries were unable even to store the books appropriately, much less make proper use of them, is a different matter.

With at least two branches-one in Moscow, the other in Leningrad-the Gosfond functioned through committees that met periodically to distribute the captured books to Soviet libraries. For example, in a meeting on March 14, 1946, a 
committee distributed 1,857 crates from some thirty institutional and private libraries (including those of top Nazis such as von Ribbentrop and Goebbels) among five Soviet libraries: the National Lenin Library of the U.S.S.R., the National Historical Library, the National Polytechnical Library, the National Library for Foreign Literature, and the National SaltykovShchedrin Public Library. ${ }^{6}$

It is noteworthy that both the trophy commissions in Germany and the allocation committees in the Soviet Union were composed of specialists from the Soviet Union's most important libraries, each striving to have its own personnel on the committees to assert its claims. Despite an allocation ranking that evolved out of their deliberations, rivalries occurred; in particular, the National Library for Foreign Literature felt it had been shortchanged. Although its director, Margarita Ivanovna Rudomino, was deputy head of a group of colleagues who selected museum and library holdings for removal to the Soviet Union, materials she had chosen for her own library later went to others because she was not present in the Soviet Union during the distribution process. She subsequently obtained permission from the highest authorities for a redistribution in favor of her library. This indicates the possibility that other, undocumented redistributions may have taken place among Soviet libraries in later years.

The last link in the transfer chain was the receiving institutions' acknowledgment of the arrival of the works allotted to them. The Committee for the Affairs of Cultural and Educational Institutions often requested information from libraries concerning their receipts. The following report from the director of the Lenin Library in Moscow offers some insights into the work of the Gosfond:

In 1947, the Lenin Library will complete the processing of its allotment of trophy literature. A total of
600,000 books and periodicals has been processed; 315,000 of these were inventoried during the previous year. Experience has confirmed the appropriateness and efficiency of our procedures for incorporating trophy literature into the holdings of the Lenin Library. We have guaranteed both its intactness and its utilization, because it is listed in a separate catalog, with a notation of all duplicates; later ... these can be provided with catalog cards and passed on to other libraries.

Based on our good experience in processing this material, I feel it is necessary to question the advisability of leaving such an enormous amount of literature at the continuing disposition of the Gosfond, which can neither take charge of it nor process it even minimally. I propose that the literature now under the jurisdiction of the Gosfond, about 700,000 books and periodicals, be transferred to the Lenin Library, so that it can be processed by the end of the year 1947. The cost for this work would come to about 600,000 rubles. In addition, it would be desirable to assign to us for the duration of the work those Gosfond employees who currently are responsible for the preservation and processing of the trophy literature. It goes without saying that it will be transferred to us together with the premises in which it is stored, previously placed at the disposal of the Gosfond by the Lenin Library.

In closing, I would like to emphasize that this would serve not only to enrich the holdings of the Lenin Library, but also to create a cataloged reserve collection upon which other libraries could draw. Duplicates comprise about $60 \%$ of the holdings, and are not of interest to the Lenin Library, which would retain no more than a third 
of the materials it processed. There is no reason to assume that our processing of the materials could work against the interests of other libraries. To the contrary, this is the only way to achieve a sensible distribution of these materials to interested libraries.

Signed: V. G. Olyshov, Director ${ }^{7}$

The archival materials to which the author had access clearly indicate that, as a rule, the work of the trophy com-

\section{most members of the trophy commissions were convinced that the ... monumental destruction of Russian library holdings, legitimized the seizure of German collections as indemnification.}

missions proceeded in an organized and purposeful fashion and that they meticulously documented most of their operations. These documents, however, lie scattered among many different archives. Hopefully, Russian and German specialists will be able to work with them and set the record straight, for the decadeslong secrecy imposed by the Russians has resulted in the only existing history of these events being the one derived from official propaganda.

\section{Motives for the Transfer of Cultural Property}

In addition to the location of missing German library collections, another issue of particular interest concerns the background for this massive removal of cultural property. What were the participants' motives, and what were their strategic political goals? Were there undeclared interests at stake?

The easiest question to answer is that of the motivation of the members of the trophy commissions. The documents connected to Margarita Ivanovna Rudomino are particularly enlightening in this regard. As early as 1944 , she had proposed to Soviet agencies that after the victory over Germany, materials should be confiscated from selected German libraries and brought to the Soviet Union. Her "List of some German libraries whose holdings it would be advantageous to transfer to the control of the U.S.S.R. independent of book reparations payments by Germany to the Soviet Union" survives in the archives of the Library for Foreign Literature in Moscow. She gave precise details about special holdings, but included only libraries and institutes that clearly could be considered National Socialist or Fascist, for example the libraries of the Foreign Policy Training Institute of the NSDAP, the Storm Troopers Leadership School, and the Wehrmacht Supreme Command. In this phase of the planning, it is credible that Rudomino's motivation was still "replacement for losses of national cultural property." But other documents indicate how far ideas about the "transfer to the jurisdiction of the U.S.S.R." had already developed. In an attachment, Rudomino included a rubric, "The relative rarity of incunables and the number of copies in German libraries," indicating, apparently on the basis of the Gesamtkatalog der Wiegendrucke, exactly which pieces the trophy commissions should target for "transfer" from Germany. In the 1944 work plan for the Library for Foreign Literature, which Rudomino headed, one goal was the "comprehensive expansion of monograph holdings in the areas of literary studies, belles lettres, and language studies." Another goal was the construction of "a new building capable of accommodating one million volumes and 2,000 daily visitors." The collections at that time comprised about 300,000 volumes.

On the basis of the available archival materials, one can assume that, like Rudomino, most members of the trophy commissions were convinced that the massive thefts of art by German special 
units, and especially their monumental destruction of Russian library holdings, legitimized the seizure of German collections as indemnification. A secondary aim was surely to damage the German economy and hamper German research. Given their own losses, one cannot blame the Russian specialists for their purposeful diversion of priceless treasures, such as medieval manuscripts, incunables, and sixteenth-century imprints. It is clear from all the documents that none of the participants doubted the rightness of their actions, even when the scope of the removals grew far beyond their original plans. On the contrary, they simply tried to gain control of a situation that was becoming unmanageable. It is also evident that these specialists felt a responsibility for the collections. In a December 1948 report entitled "Information Concerning Trophy Holdings Brought to the U.S.S.R., 1945-46," Rudomino wrote:

According to statistics supplied by the Soviet Military Administration in Germany, approximately 10 million volumes have been sent to the U.S.S.R. . . There is every reason to assume that the trophy literature allocated to libraries, ministries, and institutes [in Moscow, Leningrad, Minsk, Kiev, and elsewhere] has not yet been processed, and in large part has not even been sorted. This is due mainly to the fact that there are no additional premises available for sorting and storing the books, as well as insufficient means for library processing. ...

After the largest libraries had made their selections, about $1,000,000$ books were deposited at the Moscow and Leningrad locations of the Government Agency for Literature (Gosfond); they have not yet been distributed to other libraries. . . A large number of books has remained with ministries that have no notion of what to do with them. Titles needed by specific libraries are presently in others, where they are stacked helterskelter and mostly inaccessible, making exchanges impossible. Especially disturbing is the fact that the contents of specially selected thematic collections have been scattered and, without a central organizing body, there is no possibility of retrieving them. In many cases, complete sets of works, multi-volume titles, encyclopedias, and serial runs are broken.

The many rare books, older imprints, and artistically designed editions among the trophy holdings would be of great value to the state if they were processed and held in central libraries in the Soviet Union. The complete lack of a centralized book distribution mechanism, and insufficient government response to the actions of individual institutes that appropriated materials they did not need, have led to thefts and in some cases even to the sale of these valuable holdings. This situation remains unrectified, but it is not too late to take measures to find these books and to deposit them as state treasures in the country's national libraries....

To solve questions concerning the distribution, redistribution, sorting, and processing of trophy literature, it would be advantageous to adopt the following measures as quickly as possible:

A. Establish an appropriate national center for the locating, counting and orderly distribution and redistribution of the trophy literature that has reached the U.S.S.R. This center could be at the Gosfond in Moscow, as it already has an adequate grasp of the work and the necessary distribution experience, on the condition that it is allocated a contingent of employees and 
their salaries, along with other necessary funds and additional storage space.

B. Libraries must receive special funding for new shelves and for materials processing.

The implementation of these measures would ensure that the state would put to good use the most valuable foreign language book collections that have been brought to the U.S.S.R. ${ }^{8}$

Whether the authorities heeded Rudomino's recommendations and warnings is not completely clear, as the author could find no response to her assessment. In view of recent revelations in Russia-for example, that there are still storerooms full of unprocessed trophy literature in terrible condition-it seems very likely that the entire confiscatory operation bogged down and eventually was forgotten under its cloak of strict secrecy.

The author is convinced that if Russian authorities would allow full access to archival materials concerning the events of that time, making possible an open and honest discussion, Russian public opinion would come to favor the return of cultural property to its European countries of origin. Unfortunately, the current internal situation in the Russian Federation is such that nationalistic forces of all colors are presenting, more or less deftly, "facts and data" that cannot withstand even the most superficial scrutiny. No one in Germany denies the destruction that German troops wreaked on the Russian cultural landscape during World War II, but the Soviet Union's removal of German cultural property must come to light as well.

Colleagues and relatives of Rudomino have indicated that her views changed in the latter part of her life. The Stalinist bureaucracy stymied repeated efforts she made to persuade government authorities to return German property. Even in periods of relative liberalization, at least by Soviet standards, no one was willing to take up this hot potato. Toward the end of the 1950s, the Central Committee of the Communist Party of the Soviet Union broached a radical solution to the war booty problem: the transfer of all confiscated cultural property to the German Democratic Republic. This proposal bogged down midway when the responsible government agencies recognized the complications it would entail. Not only did they shy away from the immense effort of removing objects already integrated into Soviet institutions, but they also came to comprehend the extent of the failure of the war spoils transfer operation. Documents from this time make clear that investigating agencies had tremendous difficulties even determining the location and quantity of the trophy properties. Moreover, many institutions that housed German cultural property were loath to return it. When these institutions were able to form a political lobby, the mood shifted in the Politburo, and it discontinued the restoration process.

It is very interesting to note that the Soviet leadership's attempt at repatriation failed for the same reasons that hinder it today. Beyond the emotional barriers to repatriation, the dimensions of such an operation quickly become clear, as does the need for the money and personnel to accomplish it. Also, the institutions that currently house artifacts are again resisting their removal. For this reason, it is all the more important to illuminate the events of the 1940s.

The more difficult question to answer concerns the Soviet Union's goals in removing cultural property from Germany. Was the Soviets' intent solely compensation for their own losses in the form of artifacts from another language and cultural area? The author cannot answer this question unequivocally but can offer some information gleaned from a study of the archival materials. 
For example, on May 11, 1945, a topsecret dispatch was sent to the People's Commissioner for Internal Affairs, reporting in businesslike language that the archives of the French Republic's Interior Ministry, removed from France by German troops in 1940, had surfaced in the district of Ceská-Lípa, Czechoslovakia. Three days later, a responding directive ordered their transfer to the Central State Archives in Moscow. Twenty-eight freight carloads of these papers,deposited in a castle in the village of Oberlich, were then sent on their way to Major General Nikitinksii, director of the Main Archives of NKWD, the People's Commission for Internal Affairs. ${ }^{9}$

Many similar documents exist. One from December 15, 1945, records transports of 165 freight carloads, including 70 carloads of documents from state archives in Moldavia and the Ukraine, found in Rumania; fourteen carloads of miscellaneous archives, discovered in Czechoslovakia; sixteen carloads of papers from the district of Pilzen, received from the Allies; and sixteen carloads of French documents, including a file of one million cards with information about politically suspect persons in other countries. There were six carloads of Soviet archives, pillaged by the Germans but recovered in Poland, and twenty-eight carloads of foreign documents concerning Freemasons. The report further mentions 15,000 archival units from the Danzig State Archives and 700 from Auschwitz. A telling sentence near the end of the document observes that the shipments included a total of forty-four carloads of archives from foreign institutions that were of "political, scientifichistorical, or strategic interest to the U.S.S.R." 10

A similar communication to the Ministry for Internal Affairs reports the acquisition of 2,120,000 archival units, 53,138 of which were of French, German, English, and Polish origin; among these were 10,000 printed items and 12,000 museum objects. In another document, a "Committee for the Study of the Archives of French Army Headquarters and of the German Aviation Ministry" reported on February 25, 1946, that it had examined the following materials discovered in the Russian-occupied zone of Berlin: records of the German Aviation Ministry (1914-18 and 1933-44), including captured French technical archives; the library and records (1936-44) of the Imperial Chancellery; French military records from World War I that the Germans had removed from Paris between 1940 and 1942; some 3,600 volumes, including historical treasures, from the town hall of the Köpenick district of Berlin; archives of the President of the Weimar Republic; 100,000 letters to

\section{Even if one judges the Soviet documents very conservatively, doubts arise concerning the premise of recompense for Soviet losses.}

Hitler; and a variety of other German documents. ${ }^{11}$

Almost all this material was sent in March 1946 to the Main Archives Administration of the NKWD. Even if one judges the Soviet documents very conservatively, doubts arise concerning the premise of recompense for Soviet losses. The way the Soviets handled the archives of their own allies speaks for itself. Their documents, signed by persons who unquestionably belonged to the highest echelons of the Stalinist government, bespeak a characteristic "superpower" mentality.

In many routine documents prepared by lower-level members of the trophy commissions, one finds the expression reparations. Apparently, they assumed that the transferred cultural property was indemnification. However, this viewpoint seems confined to the lowest levels of the hierarchy. The heading of another document, marked "Secret," speaks 
another language. Entitled "Report on the shipment to the U.S.S.R. of materials and equipment found in the district of the Province of Thuringia that were expropriated without payment and do not belong to the category of reparations," it dates from October 1946, and itemizes objects confiscated from January 1 through October 15, 1946. Among them were 350,000 volumes from the library of the Duke of Gotha, received by the Academy of Sciences; 8,000 volumes from Castle Poschwitz, assigned to the Ministry for People's Education; and 400 volumes of medical books and journals from the University of Königsberg, delivered to the Ministry for Health. ${ }^{12}$

\section{German Cultural Property in Russia Today}

The figures concerning the amount of cultural property of German origin currently located in the territory of the former Soviet Union are contradictory. Again, it is important to remember that what originally was a carefully planned and massively conceived operation spun out of control, and the authorities no longer had an accurate grasp of the foreign receipts.

All the more interesting is a document from the 1950s, when the Soviet Union was considering turning over the purloined cultural properties to the former German Democratic Republic. At that time the U.S.S.R. Ministry for Culture, at the behest of the party leadership, tried to establish how much cultural property was stored in the country, and where. The final report from a survey of institutions yields the following information about books and manuscripts:

Many of the country's leading libraries hold books that were taken from Germany as trophy literature during the War.

The National Saltykov-Shchedrin Library holds about 290,000 pieces of trophy literature. Some 90,000 of these bear ownership marks of li- braries in Magdeburg, Lübeck, Bremen, and Halberstadt; a significant number are from Berlin. Most of them were printed before 1917 , and many date from the seventeenth or eighteenth centuries....

Two hundred thousand volumes of trophy literature (books, journals, maps, and musical scores) were processed, recorded, and cataloged by the Public SaltykovShchedrin Library which integrated them into its holdings and made them accessible to the public.

The National Lenin Library of the U.S.S.R. received about 760,000 volumes of trophy literature (books, journals, newspapers, musical scores), more than 5,500 manuscripts, and 670 cartons of archival materials from private ownership. The printed and manuscript collections arrived at the library at different times and from diverse sources, including the libraries of Anhalt, Potsdam, Prussia, Saxony, and the Society for Mathematics and Physics in Berlin; Breslau's Eastern Europe Library; Dresden's Art History Library; and collections of various individuals. ... A significant portion of the holdings is in highly unsatisfactory condition. Many multi-volume editions are incomplete. All of the volumes received by the National Lenin Library of the Soviet Union have been processed and incorporated into its holdings; 83,245 volumes are in secure storage, available only to readers possessing special authorization. (Pursuant to a recent decision, preparations are currently under way to transfer to the German Democratic Republic materials from the Prussian State Library and other libraries, as well as from German city archives, which have been stored in the National Lenin Library.) 
The holdings of the Lenin Library also include titles from the Leipzig Book Museum (about 600 volumes), among them incunables and sixteenth-century imprints, and historic collections of book bindings and binding materials. The collection contains a significant number of milestones in the history of printing. The most valuable is a "42-line Bible," printed by Gutenberg between 1454-55 (one of twelve remaining copies on vellum).

The library also holds a manuscript collection from the Prussian State Library with works by Mommsen, Chamisso, Fichte, [and others. ... . In addition, the Lenin Library possesses a collection of Freemasonry literature, as well as books in various German dialects.

The National Conservatory in Kiev houses a portion of the Berlin Music Library, amounting to 5,170 pieces (works of the earliest western European composers, including first editions and autographs). All have been stamped and integrated into the holdings of the Kiev Conservatory. ${ }^{13}$

Whether these particular figures are the final truth appears doubtful, as many Russian institutes, museums, and libraries even today have no real grasp of how many "trophies" they received and where and when these were stored, integrated, or redistributed. Probably the real figures are higher. The above report offers a good starting point for determining the approximate volume of German cultural property in Russia before its partial transfer to the German Democratic Republic.

In May 1995, Russia celebrated the fiftieth anniversary of the victory over Germany, a victory in a war in which millions were killed, and in which the former Soviet Union lost more than twenty mil- lion people and much cultural property. Belonging to a generation that did not experience this murderous war, and having lived for a long time in Russia, where the author learned to value the country

libraries even today have no real
grasp of how many "trophies"
they received and where and when
these were stored, integrated, or
redistributed.

and its people and made many friends, he is convinced that many people, especially younger ones, believe it is finally time to promote a new relationship between Germany and Russia. A decisive prerequisite for this effort is that both sides clear up debts remaining from World War II. Germans and Russians must come to agreement with each other on the issue of "cultural property transferred due to war." They must lay problems, data, and facts openly on the table. The German side is ready to be of help to Russian colleagues in their inquiries concerning missing Russian cultural property, but it seeks support from the Russians in the search for missing German cultural property.

\section{Postscript}

On March 17, 1995, the author had an opportunity to speak with Grigory Kozlov and Konstantin Akinsha, two scholars who for years have been working to establish the facts concerning the transfer of cultural property from Germany to the Soviet Union. They have succeeded in obtaining copies of materials from various Russian archives (unfortunately not accessible to the author in the course of his research) so that by now an almost complete record of the events of that time is available. After an examination of these papers and a long conversation with the two men, the author became convinced that the nexus which he could not prove completely in his article did in fact exist, 
particularly with regard to the highest echelon of Soviet leadership, above the level of the so-called trophy commissions. These documents establish without a doubt the thesis that the Stalinist leadership secretly and unilaterally ordered the removal of cultural property from Germany to the Soviet Union beyond the scope of any officially pledged reparations agreements among the Allies (none were ever reached in the area of cultural property!) or other international accords. Akinsha and Kozlov are preparing publications on this topic. Following is a brief sketch of the links in the chain that were missing from this article.

Immediately after the Yalta conference (February 4-11, 1945), at which the Soviet Union and the Allies came to an agreement concerning the amount of reparations they would require Germany to pay, Stalin, as chairman of the National Committee for Defense (Gosudarstvennii Komitet Oborony/GKO), issued a special command ordering the reorganization of the Red Army's Chief Division for Trophies into "trophy battalions" or "trophy commissions." He reoriented the division

\section{Many of those with local responsi- bilities acted according to the precept: "Above all, take every- thing with you."}

from its earlier mission of obtaining all materials that could be of any importance for the war effort against Nazi Germany, toward capturing valuable materials in Poland and Germany. It is abundantly clear that these trophies had nothing to do with the negotiated reparations; they were to be obtained in addition to them.

The most important body involved in this undertaking was the Special Committee for Germany, created under the National Committee for Defense by a decree of the GKO on February 25, 1945. This organization remained so secret that it was never mentioned in any publica- tion or official statement. Its chair was G. M. Malenkov, at that time a rising star under Stalin. Besides Stalin, it was this group which was responsible for the entire so-called trophy procurement operation, and especially for cultural property that was considered spoils of war. Early on, "lists of goals" with desired objects were prepared for all of Germany. These lists contained exact descriptions of what was intended for seizure. The Special Committee issued instructions to the trophy committees and organized the trophy capture meticulously: as noted previously, a deputy for trophies was stationed at each front to supervise representatives from the armies, who ultimately were responsible for searching out known as well as potential "valuables," and especially "trophies of cultural property." Upon receiving news of discoveries in their districts, they were to inform the deputy at the front, who in turn transmitted this information to the Special Committee at the GKO. The Special Committee had instructions to contact Stalin directly about every major discovery; in the beginning, he made the decisions personally. In cases that were unclear, the Special Committee dispatched a specialist to the location. At first, the orders for all major removals of cultural property, such as that of the Dresden Art Gallery, came from Stalin himself; later the Special Committee partially assumed this responsibility. The Special Committee continued to exist after the war under the Board of People's Commissioners.

Akinsha and Kozlov show that troops on the scene carried out the Special Committee's orders far from adequately. Even during the war (the majority of the evacuations took place in its last months or immediately after its end), things began to fall apart. Many of those with local responsibilities acted according to the precept: "Above all, take everything with you." Numerous objects and collections arrived in the Soviet Union without 
documentation. Nor did the transport operations always go off without a hitch: many items were damaged, some were lost. Security at interim storage locations was poor, and much was stolen. Immediately after the war itself, an incredible competition began among the trophy committees and battalions. Reality proved to be more complicated than the orders of the Special Committee. Countless objects were transported without the knowledge of administrators in Moscow, who apparently covered this up after the fact. The irregularities reached such proportions that in 1946, a special investigatory committee was established under the direction of the notorious L. S. Mekhlis. From its inquiries, it is possible to reconstruct with some accuracy the conditions under which the removals of cultural property took place.

It is significant that V. D. Sokolovskii, commander-in-chief of the Soviet armed forces in Germany and head of the Soviet Military Administration in Germany, issued a secret order as early as May 1946 to recall the battalions and terminate all removals. Nonetheless, the transports continued until the end of 1946.

It is also relevant to point out that the research of Akinsha and Kozlov notes the dispatch of three removal trains to the Soviet Union by the Committee for the Affairs of Cultural and Educational
Institutions (whose work is the main subject of this article). The numbers of these trains (177/8028, 178/8041, 176/ 8036 ) correspond to the information in the documents to which the author had access; to this extent, his findings can be considered validated.

Many thanks are due Akinsha and Kozlov for the disclosure of all these links. Without their thorough investigations, this chapter of history would still be shrouded in darkness.

\section{Author's Note Regarding the Sources}

All source materials have been translated from Russian to German as literally as possible. Because of time constraints, it was not possible to verify references to the names of places and people, or to descriptions of objects, that sometimes were vague or blurred in the Russian documents. An edited version of forty-eight key documents translated into German has just been published. ${ }^{14}$

The editor wishes to thank Nancy Boerner for translating the original German article, ${ }^{15}$ and Heidi Hutchinson, Stephen Lehmann, and Sem C. Sutter for assisting with the editing. This article appears as part of an exchange agreement with Zeitschrift für Bibliothekswesen und Bibliographie, the German counterpart to C\&RL.

\section{Notes}

1. German-Russian Treaty Regarding Cultural Cooperation, Dec. 16, 1992.

2. Restitution von Bibliotheksgut. Runder Tisch deutscher und russischer Bibliothekare in Moskau am 11. und 12. Dezember 1992, eds. Klaus-Dieter Lehmann and Ingo Kolasa, Zeitschrift für Bibliothekswesen und Bibliographie Sonderheft 56 (Frankfurt am Main: Klostermann, 1993).

3. Central National Archive of the October Revolution (Tsentral'nyi Gosudarstvennyi Arkhiv Oktiab'rskoi Revoliutsii, hereafter cited as TGAOR), F. No. 7212, Op. No. 2, Ed. chr. 4, L. 41.

4. The documents mention the following collection points: railway station Berlin-Rummelsburg, industrial plant Azeta; Stettiner railway station warehouses; and Tresckow[?] Castle; as well as field offices in the freight railway station in Radeberg near Dresden and the Leipzig Stock Exchange.

5. Archives of the Russian National Library (formerly the Saltykov-Shchedrin Library).

6. Archives of the Pan-Russian National Library for Foreign Literature.

7. Archives of the Russian National Library (formerly the National Lenin Library).

8. Archives of the Library for Foreign Literature, Administrative Division.

9. TGAOR, F. No. 4324, Op. No. 10, Ed. chr. 2249 , L.L. 70-81 - F. No. 4324 , Op. No. 10, Ed. chr. 2207, L.L. 3, 9-10. 
10. TGAOR, F. No. 5325 , Op. No. 10 , Ed. chr. 2148 , L.L. $1-4,5,5$ a.

11. TGAOR, F. No. 5325, Op. No. 10, Ed. chr. 2249, L.L. 70-81.

12. TGAOR, F. No. 7184, Op. No. /, Ed. chr. 84, L.L. 1315-20.

13. Center for the Preservation of Contemporary Documents (Tsentr Khraneniia Sovremennoi Dokumentsii), F. No. 4, Op. 16, d. 245, L.L. 169-72.

14. Die Trophaeenkommissionen der Roten Armee: Eine Dokumentensammlung zur Verschleppung von Büchern aus deutschen Bibliotheken, eds. Klaus-Dieter Lehmann and Ingo Kolasa, Zeitschrift für Bibliothekswesen und Bibliographie Sonderheft 64 (Frankfurt am Main: Klostermann, 1996).

15. Ingo Kolasa, "Sag mir wo die Bücher sind .... Ein Beitrag zu 'Beutekulturgütern' und Trophäenkommissionen,"' Zeitschrift für Bibliothekswesen und Bibliographie 42 (July/Aug. 1995): 339-64.

\section{Elegant Solutions for Preservation}

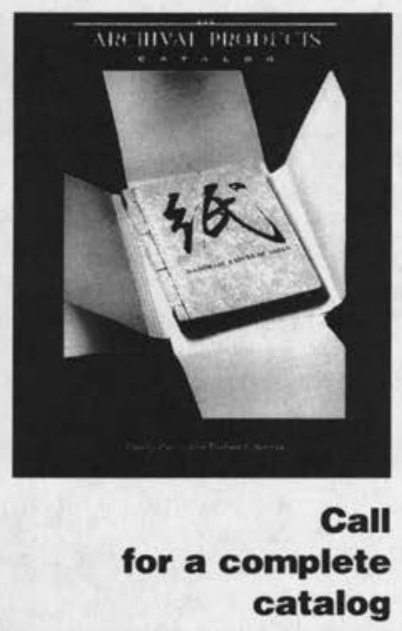

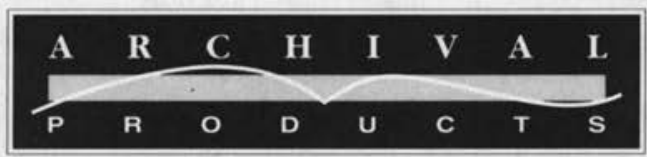

\begin{tabular}{l}
\hline Protective Enclosures \\
\hline Pamphlet Binders \\
\hline Music Binders \\
\hline Bound Four Flap Enclosures \\
\hline Tan Archival Board \\
\hline Grey/White Archival Board \\
\hline Drop Spine Archival Boxes \\
\hline Academy Folder \\
\hline Manuscript Folder
\end{tabular}

P.O. Box 1413

Des Moines, Iowa 50305-1413

PII. 800-526-5640

Fix 800-262-4091

e-mail: archival@ix.netcom.com

WEB STTE: http://www.archival.com 


\section{Literature Online}

The home of English and American literature

on the World Wide Web

LITERATURE

ONLINE

- The largest, most integrated collection of literature and literature resources on the Web

- Over 210,000 texts of poems, plays and novels in fully searchable SGML format

- Hypertext links to more than 10,000 literary texts on other websites

- Dictionaries, reference works and bibliographies in the field of English and American literature, including works not previously available electronically

- Access to electronic journals, metapages, author pages, discussion groups, general literary websites and library catalogues in English and American literature

- The Master Index - a comprehensive list of literary works and their authors accessible in Literature Online and on the Internet as a whole

- A dynamic and interactive online service

- Available in November 1996

Shakespeare Tennyson Poe Emerson Gray Dickinson Richardson ${ }_{\text {Sunbar Pope Dryden }}$ Swinburne Blake Barnes Whitmaan Marvel lyyron Coleridge Goldsmith FIELD LONGFELLOWM11 1 O Sterne WORDSWORTH Wheatley Crabbe Donne Harper Marlowe Fielding

For a 30-day free, no-obligation trial or additional information, please call (800) 752-0515.

(b CHADWYCK-HEALEY, 1101 King Street, Alexandria, VA 22314-2944

Phone: (703) 683-4890; Fax: (703) 683-7589; E-mail: mktg@chadwyck.com; Http://www.chadwyck.com 